\title{
Using Historical Sites in East Kalimantan for Education: Challenges and Opportunities
}

\author{
Muhammad Azmi \\ History Education Department, Mulawarman University, Indonesia \\ azmi@fkip.unmul.ac.id
}

\begin{tabular}{ccc}
\hline Received & Accepted & Published \\
$23 / 04 / 2018$ & $28 / 04 / 2018$ & $30 / 04 / 2018$ \\
\hline
\end{tabular}

Abstract The historical site can be used as a source of learning history, a model of learning history, media history learning, to enhance literacy history or as historical attractions. The utilization based on their shape can be divided into two, direct utilisation and indirect utilization. Constraints encountered in the utilization of the site can be divided into two, the internal problem and external problems. Internal problems in the form of time limitations, limitations of the learning ability of teachers, and facilities and infrastructure limitations. The problem form of external sites. access limitations, limitations, and limitations of supporting personnel funds.

Keywords: historical sites, East Kalimantan, history education.

Abstrak Situs sejarah dapat digunakan sebagai sumber belajar sejarah, model pembelajaran sejarah, media pembelajaran sejarah, untuk meningkatkan sejarah keaksaraan atau sebagai tempat wisata sejarah. Pemanfaatan berdasarkan bentuknya dapat dibagi menjadi dua, pemanfaatan langsung dan pemanfaatan tidak langsung. Kendala yang dihadapi dalam pemanfaatan situs dapat dibagi menjadi dua, masalah internal dan masalah eksternal. Masalah internal dalam bentuk keterbatasan waktu, keterbatasan kemampuan belajar guru, dan keterbatasan fasilitas dan infrastruktur. Bentuk masalah dari situs eksternal. keterbatasan akses, keterbatasan, dan keterbatasan dana personil pendukung.

Kata kunci : situs sejarah, Kalimantan Timur, pendidikan sejarah. 


\section{INTRODUCTION}

Indonesia is a rich country. The wealth of the rich is an invaluable gift from God Almighty. The wealth not just in the form of abundant natural resources, but also the richness of cultural diversity. The various cultures that flourished in Indonesia society make many cultural relics scattered in various areas. The cultural heritage is represented in the form of physical or non-physical. Usually, a physical-shaped relic item that was often called the art of the fact of non-shaped relics, while the physical that is abstract, both in the form of a social life often called socio-fact or be an intellectual mindset which is often called mind the fact.

Heritage artefacts are evidence of the growing cultural community in a region. Cultural development in a society indicates the formation of civilization. The rise of civilization is indicative of the flow of history that certainly happened in the community. The development of civilization of Indonesia Society surely produces various results of a culture that certainly will be passed on in the community. The cultural inheritance of the deceased in a society would become the society's mores.

In the study of the history, the legacy artefacts are tangible evidence of the existence of the interactions within the community. Such interaction would certainly produce a communication between community members. This communication then produces a flow of events that are the result of the challenge and response from the public life. All events that occurred in the history of the community for the community. History is happening in the community is told orally that was then known as oral history.

Kochhar (2008) explains that the source could be a history book, a travelogue, newspapers and magazines or historical heritage site. He further explained that the historical sources are classified into three that is the source of antiquities, written sources and oral tradition. The source can be a monumental discovery of antiquities, epigraphist objects or numismatic evidence. As for the written sources can be either Sacred Scripture, such as the book of Hindu religion, i.e. The Veda, the epics, Puranas, and Buddhist religion, i.e. the Tripitaka or in the form of written sources that is a secular literature, both private and official literature. The first form of drama, the novel, poetry, astronomy, biography, autobiography, diaries, travel stories, while the second includes tripe, saga, trip reports, court decisions, government legislation. As for the third, oral sources in the form of stories that developed in the community with information about local history.

Agung \& Wahyuni (2013), said historical learning is cooperation process between teacher and student to utilize all source, both internal and external. potential originating in yourself like interests, talents, and abilities of individual-owned basis, whereas the potential outside of yourself like the environment, the means, and the learning resources that have to be in order to achieve learning objectives certain. Porda (2009), saying that learning history has 
two elements, namely to bring learning and education. Elements of learning that is actualized elements of learning and intellectual education, while the actualized education elements are learning and moral education for a democratic and accountable to the future.

History can be studied through the ancient relics is evidence of growing civilization community in a region. The historic site is the external nature of the potential can be harnessed to specific learning objectives. Utilization of historic sites in the world of education is not impossible. The site can be used as a source of learning history (Amrullah, 2014; Ayudia, 2016; Firmanto, 2011; Hutagaol, 2015; Indriyani, 2013; Maqrifah, 2016). In addition, the site's history can also be utilized as a model of learning history (Purnamasari \& Wasino, 2011). Historical sites can also be utilized as an ingredient for the manufacture of history learning media (Indriyani, 2013; Irawati, 2015). Historic sites may also be used to enhance literacy history (Zahroh, 2014), or as historical attractions (Anwar, 2009; Hidayah, 2014).

Gordon (2016) offers the way of learning history with the term "Tourism History". In this term, he said that the study of history is a fun thing like being on holiday in the past by visiting the sites of historical relics. Learn history through heritage site allows students to learn the past directly in your life right now who are often known by the term living history. Azmi (2017) said that the living history connected with archaeology site also meet constraints in implementing it because have a burden in terms of time and funding. Kochhar (2008) mention that some possible learning history can be done directly through the historical relics in the form of monument, battlefield, historic places, old forts, tombs, temples, museums and archaeological sites.

This paper will discuss the utilization of historical sites in East Kalimantan for Education. Education referred to in this paper is a discussion of history education. The utilization of that question is the form of the use of historical sites that are integrated into the learning of history in the classroom. The discussion began with a historic site in East Kalimantan. Then proceed with the challenges and constraints in the utilization of various historical sites in East Kalimantan. Lastly, the discussion is directed at the opportunity in the utilization of historical sites in East Kalimantan for education.

\section{METHOD}

This paper is a study of the literature. Various data are collected through a review of the literature related to the discussion. The literature used is books or journals related to learning and utilization of historical sites. Based on the literature review can be drawn the conclusion of the related utilization of historic sites in East Kalimantan. 


\section{RESULT AND DISCUSSION}

\section{Historical sites in East Kalimantan}

Based on national history seminars I in Yogyakarta, national historical periodization is divided into six sections. It can be seen from the national history books Division into six parts, namely pre-history, the Hindu-Buddhist kingdoms, the era, the colonial era, the national movement, independence and post-independence period. In periodization of history in the local area, the Division of time in national history can be used as a benchmark. However, in order to be more succinct, the Hindu-Buddhist kingdoms and kingdoms were merged into the traditional time. Thus, the Division of historical periods based on heritage sites in East Kalimantan is divided into four main parts, namely the period of prehistoric times, traditional, colonial period and independence. Observationally, the majority of sites of a historic relic in East Kalimantan based on periodization most of the can be seen in table 1 .

Table 1.

The list of some historical sites in East Kalimantan

\begin{tabular}{|c|l|l|l|}
\hline No & \multicolumn{1}{|c|}{ Period } & \multicolumn{1}{|c|}{ Name of Site } & \multicolumn{1}{c|}{ Location } \\
\hline 1 & Pre-history & Caves of Sangkulirang-Mangkalihat & Sangkulirang \\
\hline 2 & \multirow{2}{*}{ Traditional Era } & Kutai Lama & Kutai Kertanegara \\
\cline { 3 - 4 } & & Berau Kingdom & Kutai Kertangera \\
\hline 3 & \multirow{2}{*}{ Colonial Era } & Sambaliung Kingdom & Berau \\
\cline { 3 - 4 } & & Colonial Sites in Loa Kulu & Loa Kulu \\
\cline { 3 - 4 } & & Oil Wells of Mathilda & Balikpapan \\
\cline { 3 - 4 } & & Colonial Sites in Gemuhan Asa & Kutai Barat \\
\cline { 3 - 4 } & & Kutai Kertanegara Palace & Kutai Kertanegara \\
\hline 4 & \multirow{2}{*}{ Kemerdekaan } & Rebellion of Sanga-sanga & Sanga-Sanga \\
\cline { 3 - 4 } & & $\begin{array}{l}\text { Memorial of coming of NICA in } \\
\text { Balikpapan }\end{array}$ & Balikpapan \\
\hline
\end{tabular}

Historical sites in East Kalimantan as in table 1 are the objects of cultural heritage are in accordance with Act No. 5 of the year 1992 about Objects of cultural heritage. The criteria mentioned in law a relic entered into objects of cultural heritage. First, the site is defined as a location containing or suspected to contain objects of cultural heritage. Second, the objects of cultural heritage are aged at least 50 years. Third, the objects of cultural heritage also have a value of history, science and culture. Based on the criteria mentioned above, the historical heritage of Borneo are mentioned in table 1 can be put in the category of cultural heritage.

Relics of prehistoric times in East Kalimantan can be seen in the caves located in the Sangkulirang Karst. In some caves found traces of human remains in the form of the Palm of the hand are more than 5000 years (Fage, Chazine, \& Setiawan, 2010). During the period, there was a traditional heritage of Kutai in the form of a stone monument was thought to be the place to tie the animal sacrifice. The stone monument was later known as the inscription Yupa (Vogel, 1918). This relic is located in the village of Kutai Lama now enters in the Kutai Regency in 1922. 
In addition, there are also some kingdoms that emerged during the traditional i.e. Kingdom of Berau, Kingdom of Sadurangas and Kingdom of Gunung Tabur.

Along with the influx of Europeans into the archipelago, Borneo region of the eastern part is also not escaping the touch of colonialism and imperialism. Initially, the Europeans came to East Kalimantan began with building the city of Balikpapan. It is undeniable, the layout of the city that lies at the mouth of Mahakam River is a major factor the Europeans set foot on Earth Etam. In addition, another factor is with the discovery of oil resources that could be exploited by Europeans. The exploitation started with the opening of the oil wells of Mathilda in Balikpapan on 1897 (Pratama, n.d.). This became the forerunner of the formation of the city of Balikpapan which is then better known as a centre of economy in East Kalimantan in the 20th century (Rahmayani, 2015).

The form of colonial heritage site also in East Kalimantan. That Sites located in Gemuhan Asa and Loa Kulu. Historic sites in Gemuhan Asa form of the Castle and the ruins of other buildings. As for the historic relics in Loa Kulu in the form of the building heritage the Netherlands spread at some point. In addition, a legacy of colonial history in the form of the castle there are also in Kutai Kertanegara. The Kutai Kertanegara was relics Palace located in the City of Tenggarong. This site use is known now as Mulawarman Museum (Larasati, Jamil, \& Johansyah, 2017). As for historic sites Rebellion of Sanga-sanga and Australia in the form of a memorial site in Balikpapan The monument was built with the aim to become a memorial of related historical events that occurred in that location.

\section{Challenges for Preservation of Historical Sites in East Kalimantan}

Utilization of historic sites in the world of education is not foreign anymore. In the study of history, archaeological evidence becomes very important in proving the occurrence of an event of history. Therefore, the study of history through historical sites is very important to note. However, problems arise when the utilization of a historical site used to present an overview of the past into the classroom. The problems that arise in the using of the historical site due to the existence of limitations that can be divided is divided into two parts, namely the problem of internal and external problems.

The problem is the internal problems that arise due to limitations in applying historical sites during the learning process in the classroom. As for the external problems are the problems that appeared due to limitations in the use of historical sites outside of the classroom. The internal problem that arises is the limitation of the time learning, teacher capability limitations and the limitations of the facilities and infrastructure. As for the external problems that arise in the utilization of the site history in the world of education is the affordability of the site, supporting power limitations and the limitations of funding. 
Internal problem-related course learning time limitations found in the field by educators. Time of learning history at school is limited according to applicable curricula. In one week, for at least the duration of learning on subjects of history maximum is just over 4 hours of lessons. In fact, the latest curriculum, duration time is only 2 hours of lessons. This is certainly a problem for educators. Another problem is the limited ability of teachers in maximizing opportunities and potentials that exist. This is certainly also associated with limited facilities and infrastructure.

Issues related to the external site affordability. The distance of the historic site and the location of the school into consideration in its utilization in the world of education. This is certainly a very difficult problem considering not all historic sites are one and the same place. In addition, the limitation of access to historical sites are also problems of its own. This is certainly a consideration because not all of the historic sites can be accessed by everyone for the sake of maintaining the sustainability of the site.

Other issues that arise in the utilization of historic sites for education is power supporters. In utilizing historic sites surely need to get help from many sides, such as assistance in the field. Technical assistance in the form of experts who know the ins and outs of the historic site. In this regard, experts played an important role in providing information that is very important related sites that are utilized. However, the reality on the ground suggests that experts who understand the site linked is very limited. As for the non-technical assistance is assistance in the areas of funding and transportation. In this case, the problem that arises is that costs be very expensive because of transportation access due to the location of the historic site. Thus, the problem that arises is the limitation of funds.

\section{Rules for Using Historical Sites for History Education}

In utilizing the historic site for history education, the need to pay attention to some things that became the benchmark in order to get maximum results. There are at least five things to note, namely, learning objectives, a form of utilization, availability of resources, methods or models used and the evaluation of learning. In the fifth such case notice, there are a number of questions that can be presented as summarized in table 2 .

Table 2.

The attention questions about using of historical sites for education

\begin{tabular}{|c|c|c|}
\hline No & Things to note & Questions \\
\hline 1 & Learning objectives & $\begin{array}{l}\text { a. Whether learning objectives to be achieved? } \\
\text { b. What is the purpose of that study in accordance with the } \\
\text { demands of the curriculum is valid? } \\
\text { c. What is the purpose of that study covers aspects of } \\
\text { cognitive, affective and psychomotor? }\end{array}$ \\
\hline 2 & Availability of resources & $\begin{array}{l}\text { a. How infrastructure available? } \\
\text { b. How are funds available? } \\
\text { c. How is labour supporter are available? }\end{array}$ \\
\hline
\end{tabular}




\begin{tabular}{|c|c|c|}
\hline & & $\begin{array}{l}\text { d. Whether the means of transport used to reach the site? } \\
\text { e. If there are references that support the related historical } \\
\text { events associated with the site? }\end{array}$ \\
\hline 3 & A form of utilization & $\begin{array}{l}\text { a. What is the shape of the desired utilization of historic } \\
\text { sites? } \\
\text { b. Whether the form in accordance with the learning } \\
\text { objectives? } \\
\text { c. Whether the form can be supported by infrastructure } \\
\text { and facilities are available? }\end{array}$ \\
\hline 4 & $\begin{array}{l}\text { The methods and models } \\
\text { used }\end{array}$ & $\begin{array}{l}\text { a. Whether the methods used can support in achieving the } \\
\text { learning objectives? } \\
\text { b. Whether the model used can support in achieving the } \\
\text { learning objectives? } \\
\text { c. Whether the method or model that is used in accordance } \\
\text { with the form of utilization of the site? }\end{array}$ \\
\hline 5 & Learning evaluation form & $\begin{array}{l}\text { a. Whether the evaluation form used? } \\
\text { b. Whether this form of evaluation in accordance with the } \\
\text { learning objectives? } \\
\text { c. Is there an appropriate instrument in accordance with } \\
\text { the evaluation form used? } \\
\text { d. What is the form of the evaluation in accordance with } \\
\text { the form of utilization of historic sites? }\end{array}$ \\
\hline
\end{tabular}

In the study of history, there are three main stages which became a reference to the utilization of the site, namely the introduction, implementation and cover. In the third stage, a number of questions asked, as summarized in table 2 can be used. The fifth aspect to note that it can be divided into three main sections. The preliminary stage of the need to pay attention to the objectives, resources and forms of utilization of the site. Stage of implementation will need to pay attention to the methods and models of instruction that is used. The closing stages of the need to pay attention to the learning evaluation form used. In summary, these stages can be seen in chart 1.
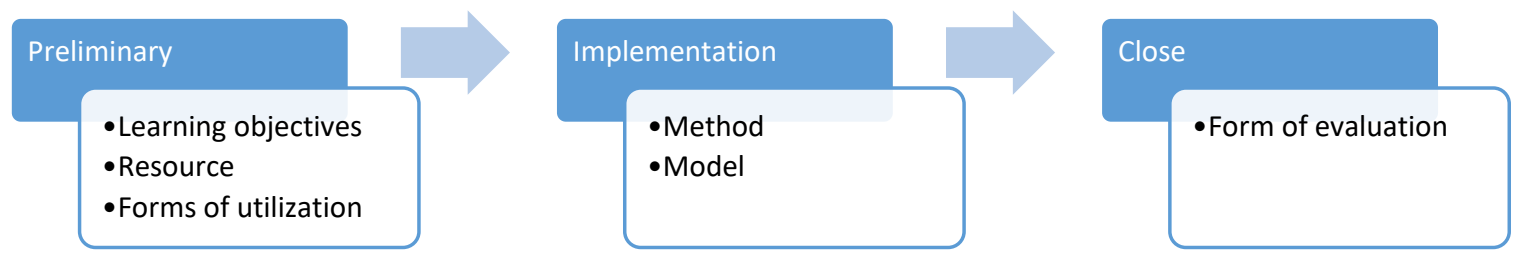

Chart 1.

The attention process of Historical Learning with Historical sites

Along with the advances in technology, the utilization of the site can be done digitally. The using of the historical site directly can be done through a program known as living history through two ways, i.e. through the museum and archaeological site. Firstly, living history connected with the museum. This program requires time and funds to visit the museum. This is certainly going a burden for teachers and students in arranging visits to museum activities. 
Secondly, the living history connected with archaeology site. The programs also meet constraints for implementation. This program will have a burden in terms of time and let the U.S. it's connected with the museums (Azmi, 2017).

The problems that arise in the utilization of historic sites appear if learners directly visit the site. Therefore, the digitizing site can become an alternative solution in addressing the problems that arise in the field. The shape of the digitizing site may take the form of software, applications, multimedia or video learning. The digital form tailored to the goal of learning the history you want. Thus, the utilization of the site can be divided into two, namely utilization directly through site visits and utilization indirectly through the digitizing site.

\section{CONCLUSION}

Historic sites can be utilized as a source of learning, the source of instructional media development, enhance the historical literacy and tourist objects of history. The utilization based on their shape can be divided into two. First, the direct utilisation through living history programs. Second, the indirect utilization through the digitization of the site. Constraints encountered in the utilization of the site can be divided into two, namely the problem of internal and external problems. Internal problems in the form of time limitations, limitations of the learning ability of teachers, and facilities and infrastructure limitations. As for the issue of affordability in the form of external sites. access limitations, limitations, and limitations of supporting personnel funds.

\section{REFERENCES}

Agung, L., \& Wahyuni, S. (2013). Perencanaan Pembelajaran Sejarah. Yogyakarta: Ombak.

Amrullah, A. R. (2014). PEMANFAATAN SITUS MEGALITIKUM DI KECAMATAN TLOGOSARI KABUPATEN BONDOWOSO SEBAGAI SUMBER BELAJAR SEJARAH.

Anwar, K. (2009). Potensi wisata budaya situs sejarah peninggalan Kerajaan Majapahit di Trowulan Mojokerto. Universitas Sebelas Maret.

Ayudia, I. (2016). PEMANFAATAN SITUS SEJARAH LOYANG MENDALE SEBAGAI SUMBER BELAJAR IPS PADA SISWA KELAS VII MTSN PEGASING KABUPATEN ACEH TENGAH. UNIMED.

Azmi, M. (2017). Learning History through Historical Movies: Bringing Living History into Classroom. In Proceedings of the International Conference on Teacher Training and Education 2017 (ICTTE 2017) (pp. 473-479). Surakarta: Atlantis Press. https://doi.org/doi:10.2991/ictte-17.2017.64

Fage, L.-H., Chazine, J.-M., \& Setiawan, P. (2010). Borneo Menyingkap Gua Prasejarah. Prancis: Le Kalimanthrope. 
Firmanto, A. (2011). SITUS BITING (Historisitas dan Pemanfaatannya sebagai Sumber Belajar Sejarah).

Gordon, A. (2016). Time Travel: Tourism and the Rise of the Living History Museum in Mid-Twentieth-Century Canada. Toronto: UBCPress. Retrieved from http://www.ubcpress.ca/books/pdf/chapters/2016/TimeTravel.pdf

Hidayah, D. (2014). PEMANFAATAN SITUS-SITUS MEGALITIK DI DESA KAMAL KECAMATAN ARJASA KABUPATEN JEMBER SEBAGAI OBYEK WISATA BUDAYA.

Hutagaol, S. (2015). PEMANFAATAN SITUS MAKAM SISINGAMANGARAJA XII SEBAGAI SUMBER PEMBELAJARAN SEJARAH DALAM MATERI PERLAWANAN BANGSA INDONESIA MENENTANG DOMINASI ASING DI SMA BALIGE. UNIMED.

Indriyani, M. (2013). SITUS TANAH WULAN DI KECAMATAN MAESAN KABUPATEN BONDOWOSO: HISTORISITAS DAN PEMANFAATANNYA SEBAGAI SUMBER PEMBELAJARAN SEJARAH.

Irawati, D. A. (2015). Media Informasi Sejarah Virtual Tour 3D Candi Singosari Kabupaten Malang. In Seminar Nasional Informatika (SEMNASIF) (Vol. 1).

Kochhar, S. K. (2008). Pembelajaran Sejarah: Terjemahan Purwanta dan Yovita Hardiwati dari Teaching of History. Jakarta: Grasindo.

Larasati, R., Jamil, J., \& Johansyah, M. (2017). Museum Mulawarman sebagai Pusat Konservasi Warisan Budaya. Yupa: Historical Studies Journal, 1(1), 93-102.

Maqrifah, N. U. R. A. (2016). SITUS SUNAN BAYAT SEBAGAI SUMBER PEMBELAJARAN SEJARAH KELAS X DI KABUPATEN KLATEN (SMA N 1 CAWAS DAN SMA N 1 BAYAT). Universitas Sebelas Maret.

Porda, H. N. (2009). Pembelajaran Sejarah. Banjarmasin: CV Batur Raya.

Pratama, A. R. (n.d.). Industri Minyak di Balikpapan Sebelum Perang Dunia II.

Purnamasari, I., \& Wasino. (2011). Pengembangan Model Pembelajaran Sejarah Berbasis Situs Sejarah Lokal di SMA Negeri Kabupaten Temanggung. Paramita: Historical Studies Journal, 21(2), 202-212.

Rahmayani, A. (2015). BALIKPAPAN PADA AWAL ABAD KE-20. Walasuji, 6(1), 127-138.

Vogel, J. P. (1918). The Yupa Inscriptions of king Mulavarman, from Koetei (East Borneo). Bijdragen Tot de Taal-, Land-En Volkenkunde van Nederlandsch-Indië, (1/2de Afl), 167-232. Retrieved from http://booksandjournals.brillonline.com/docserver/22134379/74/1/22134379_0 74_01_s04_text.pdf?expires=1524445583\&id=id\&accname=guest\&checksum=129 6221FC8EB0918CCCF66AC2FD3D8DE

Zahroh, N. L. (2014). Pemanfaatan Situs Singosari dalam Mengembangkan Literasi Sejarah Peserta Didik. J-PIPS, 1(1), 159. 